\title{
North Carolina macular dystrophy
}

\author{
INSERM
}

\section{Source}

INSERM. (1999). Orphanet: an online rare disease and orphan drug data base. North Carolina macular dystrophy. ORPHA:75327

North Carolina macular dystrophy (NCMD) is a non-progressive autosomal dominant macular disorder of congenital or infantile onset characterized by loss of central vision, the accumulation of drusen in the macula and atrophy of photoreceptor cells with a variable phenotype at macular examination. 